\title{
HUBUNGAN MOTIVASI PASIEN DENGAN KEPATUHAN KONTROL ORTHODONTIK CEKAT DI KLINIK SWASTA YOGYAKARTA
}

\section{THE CORRELATION BETWEEN PATIENTS' MOTIVATION AND COMPLIANCE OF FIXED ORTHODONTIC APPLIANCE CONTROL AT CLINICS IN YOGYAKARTA}

\author{
Seri Wahyuni ${ }^{1^{*}}$, Herastuti Sulistyani ${ }^{2}$, Siti Hidayati ${ }^{3}$ \\ 1 Jur Keperawatan Gigi Poltekkes Kemenkes Yogyakarta, email:seriwahyuni98@gmail.com* \\ 2 Jur Keperawatan Gigi Poltekkes Kemenkes Yogyakarta, email: heras_poltek@yahoo.co.id \\ ${ }^{3}$ Jur Keperawatan Gigi Poltekkes Kemenkes Yogyakarta, email: jkg.hidayati@gmail.com
}

\begin{abstract}
ABSTRAK
Perawatan orthodonti memerlukan waktu berbulan-bulan untuk menyelesaikannnya, kunjungan rutin harus ditaati. Keberhasilan perawatan orthodonti memerlukan motivasi yang tinggi dalam perawatan. Kegagalan untuk mentaati jadwal seringkali merupakan indikasi dari kurangnya kepatuhan di pihak pasien. Berbagai cara dapat dilakukan untuk meningkatkan kepatuhan kontrol, salah satunya adalah pasien dimotivasi dengan baik agar mengerti dan menghargai perlunya jadwal kunjungan yang teratur. Tujuan penelitian ini adalah diketahuinya hubungan motivasi pasien dengan kepatuhan kontrol orthodonti cekat di Yogyakarta.Penelitian ini adalah survey analitik dengan rancangan cross sectional. Pengambilan sampel pada penelitian ini menggunakan metode purposive sampling Jenis dan teknik pengumpulan data dengan menggunakan data primer diambil dari hasil kuesioner dan data sekunder diambil secara langsung pada rekam medik. Populasi penelitian ini adalah pasien orthodonti cekat di klinik Yogyakarta. Analisis data menggunakan Korelasi Kendalls Tau. Motivasi pasien orthodonti cekat diketahui sebanyak 92,3\% masuk dalam kategori motivasi tinggi. Kepatuhan kontrol pasien orthodonti cekat diketahui sebanyak $63,5 \%$ adalah pasien yang patuh kontrol. Hasil penelitian menunjukkan ada hubungan yang signifikan antara motivasi pasien dengan kepatuhan kontrol orthodonti cekat $(p=0.007)$. Dapat disimpulkan bahwa ada hubungan yang signifikan antara motivasi pasien dengan kepatuhan kontrol orthodonti cekat.
\end{abstract}

Kata Kunci : kepatuhan control, motivasi, orthodontik cekat

\begin{abstract}
Orthodontic treatment requires monthly process to complete, and doctor visit schedule must be obeyed. The success of orthodontic treatment requires high motivation. Failure to obey a schedule is often an indication of a lack of adherence to the patient. Various ways can be done to improve compliance, one of which is that the patients are motivated therefore that they understand and appreciate the need for visit schedule to ensure continuity of treatment. The purpose of this study was to investigation the relationship of patients' motivation and fixed orthodontic appliance scheduled appointment in Yogyakarta.This study was an analytical survey with cross sectional design. The retrieval of samples used purposive sampling method. The types and data collection techniques used the primary data extracted from the results of the data and the secondary data taken from medical record. The research populations are patients fixed orthodontic patients in private clinics in Yogyakarta. The data analysis used Kendalls Tau Corelation. Fixed orthodontic patients' motivation in clinics of Yogyakarta is known to be $92.3 \%$ and it belongs to high motivation category. Patients' compliance to the schedule in clinics in Yogyakarta was found to be $63.5 \%$ and it belongs to the category of obedient patients. The results of the study show significant relationships between motivation and the high level of
\end{abstract}


compliance of scheduled visits at clinic in Yogyakarta ( $p=0.007)$. There was a significant relationship between strong motivation and compliance of fixed orthodontic scheduled visits.

Keywords: compliance of visits, motivation, fixed orthodontic

\section{PENDAHULUAN}

Berdasarkan hasil Riskesdas 2017 prevalensi nasional masalah gigi dan mulut adalah $57,6 \%$, jumlah ini meningkat apabila dibandingkan dengan hasil Riskesdas 2013 sebesar 25,9\%. Prevalensi maloklusi bervariasi di seluruh belahan dunia pada berbagai populasi. ${ }^{1}$ Angka kejadian maloklusi di Indonesia cukup tinggi. Prevalensi maloklusi pada tahun 2008 di Indonesia mencapai $80 \%$ dan menduduki peringkat ketiga setelah karies gigi dan penyakit periodontal. $^{2}$ Keadaan maloklusi akan berdampak pada estetika wajah, masalah pada fungsi oral dan penyebab terjadinya penyakit periodontal. ${ }^{3}$ Pencegahan penyakit gigi merupakan salah satu aspek paling penting dari pemeliharaan gigi. Orthodonti bisa dikaitkan dengan pencegahan dalam tiga cara yaitu mencegah maloklusi, mencegah penyakit-penyakit gigi yang lain dan mencegah penyakit gigi selama periode perawatan orthodonti. ${ }^{4}$

Tujuan utama dari perawatan orthodonti adalah mendapat penampilan dentofasial yang menyenangkan secara estetik dengan fungsi yang baik dan gigi dalam posisi stabil. ${ }^{5}$ Saat ini perawatan orthodonti dengan alat cekat lebih popular dibandingkan alat lepasan sebab dapat mengatasi penyimpangan oklusi yang sangat beragam dengan hasil yang baik. ${ }^{3}$ Alat orthodonti cekat akan menghasilkan pergerakan yang lebih kompleks bila dibandingkan dengan alat orthodonti lepasan. ${ }^{6}$

Hasil penelitan yang telah dilakukan menyatakan bahwa sebagian besar responden pasien orthodonti dewasa yang diteliti memilih penampilan sebagai motivasi utama perawatan orthodonti. Kehilangan gigi, kebutuhan restorasi dan kerusakan jaringan periodontal menjadi alasan lain pasien dewasa menggunakan perawatan orthodonti. ${ }^{7}$ Motivasi pada dasarnya merupakan interaksi seseorang dengan situasi tertentu yang dihadapinya. Motivasi adalah suatu alasan (reasoning) seseorang untuk bertindak dalam rangka memenuhi kebutuhan hidupnya. ${ }^{8}$

Perawatan orthodonti memerlukan waktu berbulan-bulan untuk menyelesaikannnya, kunjungan rutin harus ditaati dengan interval 4-6 minggu. Semua pasien harus menunjukkan motivasi yang tinggi dan kesungguhan dalam perawatan. Selama perawatan orthodonti kegagalan untuk menaati jadwal seringkali merupakan indikasi dari kurangnya kepatuhan di pihak pasien. Kegagalan yang berulang-ulang akan mengurangi kualitas perawatan. Waktu perawatan akan menjadi lebih panjang serta kerusakan pada gigi-gigi dan struktur pendukung dapat terjadi. Pasien yang dimotivasi dengan baik akan mengerti dan menghargai perlunya jadwal kunjungan yang teratur untuk memastikan kontinuitas dari perawatan dan pergerakan gigi yang memuaskan. ${ }^{5}$

Klinik gigi swasta yang berada di Jl. Melati Kulon Baciro Yogyakarta, merupakan pelayanaan kesehatan gigi dan mulut yang menyediakan berbagai pelayanan termasuk pemasangan alat orthodonti cekat yang ditangani dokter gigi spesialis yang berpengalaman. Klinik didukung dengan peralatan yang canggih serta fasilitas klinik yang nyaman. Klinik mempunyai 1 orang dokter spesialis orthodonti, jumlah pasien kontrol orthodonti cekat dalam 1 bulan sekitar 60 orang.

Berdasarkan latar belakang maka penulis tertarik untuk meneliti tentang hubungan motivasi pasien dengan kepatuhan kontrol orthodonti cekat di Klinik Swasta Yogyakarta. Tujuan Penelitian adalah diketahuinya hubungan motivasi pasien dengan kepatuhan kontrol orthodonti cekat di klinik swasta Yogyakarta.

\section{METODE}

Penelitian ini adalah survey analitik dengan rancangan cross sectional. Populasi dalam 
penelitian ini adalah pasien orthodonti cekat di klinik swasta Yogyakarta sebanyak 60 orang. Pengambilan sampel pada penelitian ini menggunakan metode purposive sampling ${ }^{9}$. Kriteria sampel yaitu pasien memakai alat orthodonti cekat $\geq 12$ bulan, pasien memakai alat orthodonti cekat rahang atas dan bawah dan umur 15-40 tahun. Besar sampel yang didapatkan dari perhitungan dengan rumus Slovin adalah 52 responden.

Tempat pelaksanaan penelitian ini adalah di klinik swasta Yogyakarta. Penelitian dilakukan pada bulan Oktober-Nopember 2017. Variabel independent (pengaruh) yaitu motivasi pasien orthodonti cekat dan variabel dependent (terpengaruh) kepatuhan kontrol orthodonti cekat.

Cara pengukuran motivasi pasien orthodonti cekat dilakukan dengan pengisian kuesioner oleh subjek peneliti. Kriteria untuk tingkat motivasi yaitu motivasi tinggi adalah apabila responden memperoleh nilai 61-100 dan motivasi rendah adalah apabila responden memperoleh nilai 20-60. Kepatuhan kontrol orthodonti cekat. Data diperoleh dari rekam medis kunjungan pasien yang dijadwalkan untuk kontrol. Bentuk kepatuhan pasien yang diukur dalam penelitian ini yaitu kepatuhan pasien dalam melakukan kontrol rutin dalam 12 bulan terakhir, yang biasanya dilakukan 46 minggu sekali. Pasien dikategorikan dalam penelitian ini yaitu patuh adalah apabila pasien selalu melakukan kontrol rutin dalam 12 bulan terakhir, yang biasanya dilakukan 46 minggu sekali atau apabila pasien pernah tidak menepati jadwal kontrol sebanyak 1-3 kali dilihat dari rekam medik dan tidak patuh adalah apabila pasien pernah tidak menepati jadwal kontrol sebanyak lebih dari 3 kali dilihat dari rekam medik.

Data dalam penelitian ini diolah dengan teknik analisis statistik yaitu analisis korelasi menggunakan metode korelasi Kendall's tau dengan tingkat kepercayaan 95\% menggunakan aplikasi SPSS. Korelasi Kendall's tau dapat digunakan untuk menyelesaikan dua variabel dengan skala data ordinal ${ }^{10}$.
HASIL

Hasil penelitian adalah sebagai berikut:

Karakteristik responden dalam penelitian ini dibedakan menurut kelompok umur dan jenis kelamin.

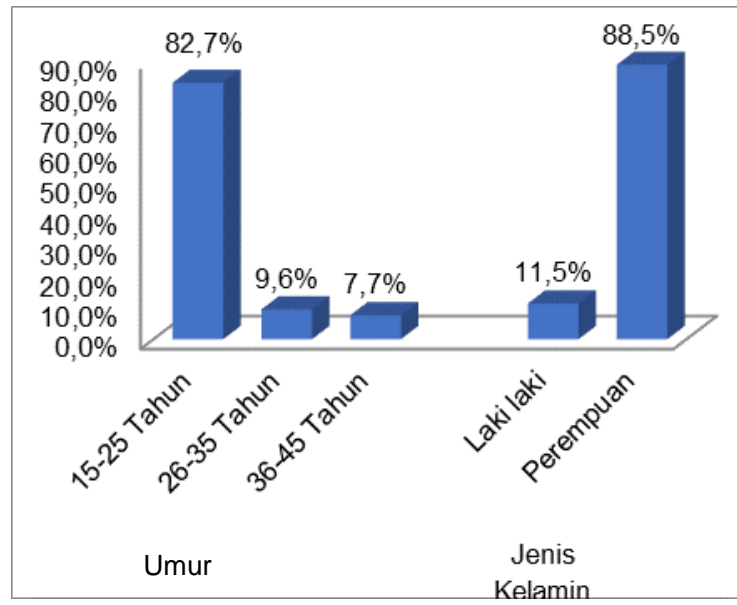

\section{Gambar 1. Distribusi Responden BerdasarkanUmur dan Jenis Kelamin Pasien Orthodonti Cekat}

Berdasarkan gambar 1. dapat diketahui bahwa karakteristik responden tertinggi adalah kelompok umur 15-25 sebanyak 43 orang $(82,7 \%)$ dan jenis kelamin perempuan yaitu sebanyak 46 orang $(88,5 \%)$.

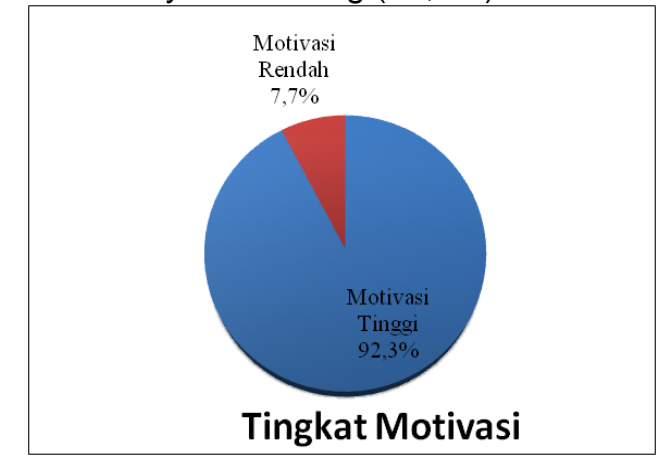

Gambar 2. Distribusi Frekuensi Tingkat Motivasi Pasien Orthodonti Cekat

Berdasarkan gambar 2 dapat diketahui motivasi pasien orthodonti cekat di klinik swasta Yogyakarta sebanyak 48 orang $(92,3 \%)$ masuk dalam kategori motivasi tinggi. 
Tabel 1. Tabulasi Silang Tingkat Motivasi dengan Umur

\begin{tabular}{|c|c|c|c|c|}
\hline \multicolumn{5}{|c|}{ Umur/Tahun } \\
\hline $\begin{array}{l}\text { Tingkat } \\
\text { Motivasi }\end{array}$ & $\begin{array}{c}15-25 \\
(\%)\end{array}$ & $\begin{array}{c}26-35 \\
(\%)\end{array}$ & $\begin{array}{c}36-45 \\
(\%)\end{array}$ & Total \\
\hline Tinggi & $\begin{array}{c}40 \\
(76.9)\end{array}$ & $\begin{array}{c}4 \\
(7,7)\end{array}$ & $\begin{array}{c}4 \\
(7,7)\end{array}$ & $\begin{array}{c}48 \\
(92,3)\end{array}$ \\
\hline Rendah & $\begin{array}{c}3 \\
(5,8)\end{array}$ & $\begin{array}{c}1 \\
(1,9)\end{array}$ & 0 & $\begin{array}{c}4 \\
(7,7)\end{array}$ \\
\hline Total & $\begin{array}{c}43 \\
(82,7)\end{array}$ & $\begin{array}{c}5 \\
(9,6)\end{array}$ & $\begin{array}{c}4 \\
(7,7)\end{array}$ & $\begin{array}{c}52 \\
(100)\end{array}$ \\
\hline
\end{tabular}

Berdasarkan tabel 3. dapat diketahui kategori motivasi tinggi dengan responden tertinggi adalah kelompok umur $15-25$ sebanyak 40 orang $(76,9 \%)$.

Tabel 2. Tabulasi Silang Tingkat Motivasi dengan Jenis Kelamin
Tabel 3. Tabulasi Silang Kepatuhan Kontrol Orthodonti dengan Umur

\begin{tabular}{ccccc}
\hline $\begin{array}{c}\text { Kepatuhan } \\
\text { Kontrol }\end{array}$ & $\begin{array}{c}\text { Umur } \\
\mathbf{1 5 - 2 5} \\
\text { Tahun }\end{array}$ & $\begin{array}{c}\mathbf{2 6 - 3 5} \\
\text { Tahu } \\
\mathbf{n}\end{array}$ & $\begin{array}{c}\mathbf{3 6 - 4 5} \\
\text { Tahun }\end{array}$ & Total \\
\hline \multirow{2}{*}{ Patuh } & 27 & 3 & 3 & 33 \\
& $(52 \%)$ & $(5,7 \%)$ & $(5,7 \%)$ & $(63,4 \%)$ \\
Tak Patuh & 16 & 2 & 1 & 19 \\
& $(30,8 \%)$ & $(3,9 \%$ & $(1,9 \%)$ & $(36,6 \%)$ \\
\hline \multirow{2}{*}{ Total } & 43 & 5 & 4 & 52 \\
& $(82,8 \%)$ & $(9,6 \%)$ & $(7,6 \%)$ & $(100 \%)$ \\
\hline
\end{tabular}

Berdasarkan tabel 3 dapat diketahui pasien yang patuh kontrol dengan responden tertinggi adalah kelompok umur 15-25 sebanyak 27 orang (52\%).

Tabel 4. Tabulasi Silang Kepatuhan Kontrol Orthodonti dengan Jenis Kelamin

\begin{tabular}{|c|c|c|c|c|c|c|c|}
\hline \multirow{2}{*}{$\begin{array}{c}\text { Tingkat } \\
\text { Motiva } \\
\text { si }\end{array}$} & \multicolumn{2}{|c|}{ Jenis Kelamin } & \multirow[b]{2}{*}{ Total } & \multirow[b]{2}{*}{$\begin{array}{c}\text { Kepatuhan } \\
\text { Kontrol }\end{array}$} & \multicolumn{2}{|c|}{ Jenis Kelamin } & \multirow[b]{2}{*}{ Total } \\
\hline & Laki-laki & Perempuan & & & Laki-laki & Perempuan & \\
\hline Tinggi & $\begin{array}{c}6 \\
(11,5 \%)\end{array}$ & $\begin{array}{c}42 \\
(80,8 \%)\end{array}$ & $\begin{array}{c}48 \\
(92,3 \%)\end{array}$ & Patuh & $\begin{array}{c}6 \\
(11,5 \%)\end{array}$ & $\begin{array}{c}27 \\
(52 \%)\end{array}$ & $\begin{array}{c}33 \\
(63,5 \%)\end{array}$ \\
\hline Rendah & 0 & $\begin{array}{c}4 \\
(7,7 \%)\end{array}$ & $\begin{array}{c}4 \\
(7,7 \%)\end{array}$ & Tidak Patuh & 0 & $\begin{array}{c}19 \\
(36,5 \%) \\
\end{array}$ & $\begin{array}{c}19 \\
(36,5 \%) \\
\end{array}$ \\
\hline Total & $\begin{array}{c}6 \\
(11,5 \%))\end{array}$ & $\begin{array}{c}46 \\
(88,5 \%)\end{array}$ & $\begin{array}{c}52 \\
(100 \%)\end{array}$ & Total & $\begin{array}{c}6 \\
(11,5 \%) \\
\end{array}$ & $\begin{array}{c}46 \\
(88,5 \%) \\
\end{array}$ & $\begin{array}{c}52 \\
(100 \%) \\
\end{array}$ \\
\hline
\end{tabular}

Berdasarkan Tabel 2 dapat diketahui kategori motivasi tinggi dengan responden tertinggi adalah jenis kelamin perempuan sebanyak 42 orang $(80,8 \%)$.

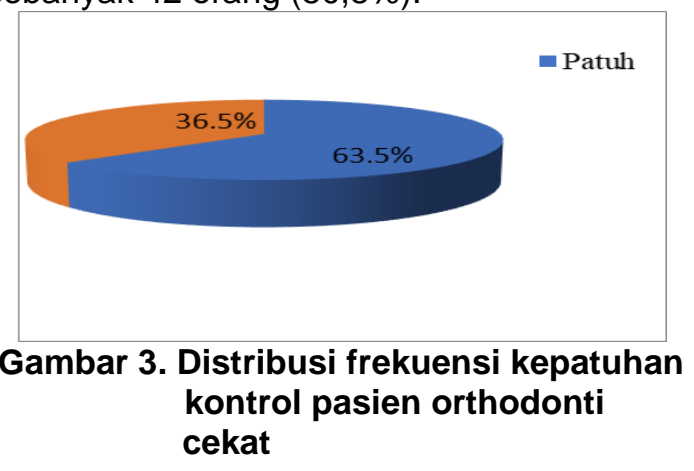

Berdasarkan gambar 3 dapat diketahui kepatuhan kontrol pasien orthodonti cekat di klinik swasta Yogyakarta sebanyak 33 orang $(63,5 \%)$ adalah pasien yang patuh kontrol.
Berdasarkan tabel 4. dapat diketahui pasien yang patuh kontrol dengan responden tertinggi adalah jenis kelamin perempuan sebanyak 27 orang (52\%).

Tabel 5. Tabulasi Silang Hubungan Motivasi Pasien dengan Kepatuhan Kontrol Orthodonti Cekat

\begin{tabular}{rccc}
\hline $\begin{array}{c}\text { Tingkat } \\
\text { Motivasi }\end{array}$ & Kepatuhan Kontrol & Total \\
& \multicolumn{3}{c}{$\begin{array}{c}\text { Tidak } \\
\text { Patuh }\end{array}$} \\
\hline Tinggi & 33 & 15 & 48 \\
Rendah & $(63,4 \%)$ & $(28,8 \%)$ & $(92,3 \%)$ \\
& 0 & 4 & 4 \\
$(7,7 \%)$ & $(7,7 \%)$ \\
\hline Total & 33 & 19 & 52 \\
& $(63,5 \%)$ & $(36,5 \%)$ & $(100 \%)$ \\
\hline
\end{tabular}


Berdasarkan tabel 5 . Hasil penelitian diatas terdapat 33 orang $(63,5 \%)$ responden yang mempunyai motivasi tinggi untuk patuh kontrol.

Uji korelasi dilakukan untuk mengetahui apakah ada hubungan apakah ada hubungan antara variabel motivasi dengan variabel kepatuhan kontrol orthodonti. Uji korelasi Kendall's Tau hubungan motivasi pasien dengan kepatuhan kontrol orthodonti cekat di klinik swasta Yogyakarta diketahui bahwa ada 52 responden dalam penelitian. Kemudian nilai sig. (2-tailed) adalah 0.007, Correlation Coefficient (koefisien korelasi) sebesar 0.380. hal ini menunjukkan ada hubungan yang bermakna antara motivasi pasien dengan kepatuhan kontrol orthodonti cekat di klinik swasta Yogyakarta.

\section{PEMBAHASAN}

\section{Karakteristik Responden}

Karakteristik responden dalam penelitian ini dibedakan menurut kelompok umur dan jenis kelamin di klinik swasta Yogyakarta bahwa karakteristik responden tertinggi adalah kelompok umur 15-25 tahun sebanyak 43 orang $(82,7 \%)$ dan jenis kelamin perempuan yaitu sebanyak 46 orang $(88,5 \%)$. Penggunaan alat ortodonti lebih banyak diminati oleh kelompok umur 15-25 tahun (remaja). Terdapat 81,5\% pasien remaja yang menggunakan alat ortodonti ${ }^{11}$. Masa remaja sebagai masa pertumbuhan dan perkembangan yang terjadi setelah masa kanak-kanak dan sebelum masa dewasa dimulai ${ }^{12}$. Pada masa ini terjadi perubahan baik fisik, mental maupun psikososial. Perubahan yang terjadi membuat remaja sering merasa tidak puas dengan penampilan wajahnya karena menurut remaja penampilan wajah adalah hal yang sangat penting dari penampilan fisik ${ }^{13}$.

Salah satu faktor yang dapat mempengaruhi kesadaran akan kelainan yang diderita dan kebutuhan akan perawatan adalah tingkat pemahaman akan susunan gigi yang baik. Hal ini dipengaruhi oleh usia, jenis kelamin, pendidikan, sosial ekonomi dan estetik.
Pada masa akil balik, kepekaan terhadap penampilan wajah meningkat dan keinginan untuk diterima oleh lingkungannya membuat remaja semakin sadar akan dirinya ${ }^{14}$.

Adanya perbedaan jumlah sampel laki-laki dan perempuan dikarenakan perempuan lebih tidak percaya diri ketika terdapat malposisi pada gigi yang mengurangi nilai estetika pada dirinya. Namun hal itu tidak terlalu menjadi perhatian bagi laki-laki, sehingga kebanyakan jumlah pengguna alat orthodonti adalah perempuan ${ }^{15}$. Kebutuhan perawatan orthodonti perempuan lebih banyak menginginkan perawatan orthodonti dibandingkan lakilaki karena ingin hasil yang maksimal dari segi estetika gigi dan wajah, hal ini membuktikan bahwa perempuan lebih menghargai penampilan dibandingkan laki-laki ${ }^{16}$. Sebanyak 39 responden pengguna alat orthodonti cekat, 36 $(92,3 \%)$ di antaranya adalah responden berjenis kelamin perempuan dan sisanya adalah responden berjenis kelamin laki laki $i^{17}$.

2. Motivasi pasien orthodonti cekat di klinik swasta Yogyakarta.

Berdasarkan motivasi pasien orthodonti cekat di klinik swasta Yogyakarta diketahui sebanyak 48 orang $(92,3 \%)$ masuk dalam kategori motivasi tinggi, sedangkan 4 orang $(7,7 \%)$ masuk dalam kategori motivasi yang rendah. Hasilnya lebih banyak pasien yang memiliki motivasi tinggi dalam perawatan orthodonti dengan karakteristik responden tertinggi adalah kelompok umur 15-25 sebanyak 40 orang $(76,9 \%)$ dan jenis kelamin perempuan sebanyak 42 orang $(80,8 \%)$.

Motivasi perawatan orthodonti mengandung empat aspek yaitu keparahan yang dirasakan, dental esthetic, kesediaan untuk perawatan dan kepatuhan kontrol. Aspek keparahan yang dirasakan berkaitan tentang bagaimana persepsi seseorang dengan penampilan wajah, keadaan rongga mulut dan susunan gigi geligi. Penampilan wajah 
memiliki peran penting dalam kehidupan manusia dan hubungan interpersonal. Aspek dental esthetic tentang peran gigi geligi dalam keindahan wajah seseorang. Penelitian ini menunjukkan bahwa motivasi tertinggi dalam melakukan perawatan terkait dental esthetic sebanyak $77,88 \%$ karena pasien ingin memiliki senyum yang indah. Aspek kesediaan untuk perawatan berkaitan tentang harapan dan kesiapan pasien untuk melakukan perawatan orthodonti cekat sebanyak $71,24 \%$. Kesediaan pasien untuk melakukan perawatan dapat meningkatkan perilaku kooperatif pasien ortodotik cekat. Aspek kepatuhan kontrol berkaitan tentang kepatuhan pasien dalam melakukan kunjungan rutin ke dokter gigi sesuai jadwal yang ditentukan sebanyak $62,82 \%$ dan keparahan yang dirasakan hanya $54,67 \%$. Subjek yang memiliki motivasi tinggi sebanyak 55 orang $(57,3 \%)$ dan rendah sebanyak 41 orang $(42,7 \%)^{17}$.

Mayoritas responden adalah anak-anak dan remaja 41 orang, dan $67 \%$ adalah anak perempuan. Responden dengan motivasi yang baik adalah 48 orang; motivasi yang adil 30 orang dan motivasi rendah adalah 2 orang. Hasil ini menunjukkan bahwa sebagian besar responden adalah remaja pada periode ini, mereka butuh fisik yang baik untuk kehidupan sosial mereka Hasilnya menunjukkan sebagian besar responden memiliki motivasi yang baik untuk perawatan orthodonti. Motivasi adalah keinginan manusia yang berhubungan dengan psikologi manusia seperti sikap, permintaan dan kepuasan. Motivasi itu penting sebagai faktor penyalur dan penunjang manusia. Psikomotor bekerja keras untuk mendapatkan hasil yang optimal. Ada 2 jenis motivasi yaitu motivasi internal dan motivasi eksternal. Remaja dan orang dewasa memiliki motivasi internal, yang merupakan motivasi mereka sendiri dengan keinginan untuk posisi gigi yang benar dan pengunyahan. Remaja dan orang dewasa sebagian besar memiliki motivasi intrinsik yang merupakan motivasi dari mereka sendiri untuk memperbaiki posisi gigi dan pengunyahan fungsi ${ }^{18}$. Pasien dewasa yang mendapat perawatan orthodonti biasanya mempunyai motivasi cukup tinggi $i^{5}$.

3. Kepatuhan kontrol pasien orthodonti cekat di klinik swasta Yogyakarta.

Berdasarkan hasil penelitian dapat diketahui kepatuhan kontrol pasien orthodonti cekat di klinik swasta Yogyakarta sebanyak 33 orang $(63,5 \%)$ adalah pasien yang patuh kontrol, sedangkan 19 orang $(36,5 \%)$ adalah pasien yang tidak patuh kontrol. Hasilnya lebih banyak pasien yang patuh kontrol dengan karakteristik responden tertinggi adalah kelompok umur $15-25$ sebanyak 27 orang (52\%) dan jenis kelamin perempuan sebanyak 27 orang (52\%).

Jumlah responden 94 orang diketahui tingkat kooperatif pasien dengan perawatan orthodonti cekat diperoleh hasil 41 orang responden $(43,6 \%)$ termasuk golongan pasien yang kooperatif, 41 orang responden $(43,6 \%)$ termasuk golongan pasien cukup kooperatif, 7 orang responden $(7,4 \%)$ termasuk golongan pasien tidak kooperatif, dan 5 orang responden (5,3\%) termasuk golongan pasien sangat tidak kooperatif ${ }^{19}$. Kooperatif pasien dalam perawatan orthodonti merupkan hal yang sangat penting dalam perawatan orthodonti.

Siswa melakukan kontrol piranti ortodonti cekat sesuai jadwal yang ditentukan yaitu $83,5 \%$ dan hanya sebagian kecil yang tidak pernah melakukan kontrol piranti $3,9 \%{ }^{19}$. Sebagian besar pasien melakukan kontrol ortodonti cekat sesuai jadwal yang ditentukan ${ }^{20}$.

Pasien mengerti perlunya jadwal kunjungan yang teratur selama berbulanbulan sesuai anjuran dokter gigi yang merawatnya untuk mendapatkan hasil perawatan orthodonti yang memuaskan. 
4. Hubungan motivasi pasien dengan kepatuhan kontrol orthodonti cekat di klinik swasta Yogyakarta

Berdasarkan hasil penelitian diketahui bahwa ada 52 responden. Nilai sig. (2tailed) adalah 0.007, sebagaimana dasar pengambilan keputusan diatas maka dapat disimpulkan bahwa ada hubungan yang signifikan antara motivasi terhadap kepatuhan kontrol. Selanjutnya diketahui Correlation Coefficient (koefisien korelasi) sebesar 0.380 maka nilai ini menunjukkan hubungan antara motivasi dengan kepatuhan kontrol.

Berdasarkan hasil penelitian diatas terdapat 33orang $(63,4 \%)$ yang mempunyai motivasi tinggi untuk rutin kontrol, dan 15 orang (28,8\%) motivasi tinggi tidak rutin kontrol. Responden yang motivasi rendah tidak ada yang rutin kontrol dan 4 orang $(7,7 \%)$ yang tidak rutin kontrol.

Motivasi pasien dalam melakukan perawatan orthodonti adalah merupakan salah satu faktor yang mempengaruhi tingkat kepatuhan kontrol orthodonti ${ }^{19}$. Pasien dimotivasi dengan baik untuk mengerti dan menghargai perlunya jadwal kunjungan yang teratur untuk memastikan kontinuitas dari perawatan dan gerakan gigi yang memuaskan. Kunjungan rutin harus ditaati dengan interval 2-3 minggu sehingga perawatan orthodonti berhasil ${ }^{5}$.

Pasien memiliki motivasi yang tinggi dan menaati jadwal kontrol untuk memperoleh keberhasilan perawatan orthodonti cekat. Motivasi yang rendah selama perawatan akan mempengaruhi jalannya perawatan karena pasien bertanggung jawab dalam merawat alat, pemakaian alat tambahan pada orthodonti cekat serta kunjungan berkala ke dokter gigi. Semakin tinggi motivasi seseorang maka akan semakin patuh untuk kontrol orthodonti

\section{SIMPULAN DAN SARAN}

Simpulan dari penelitian ini yakni pasien orthodonti cekat di klinik swasta Yogyakarta memiliki motivasi tinggi dalam perawatan orthodonti dan kepatuhan untuk kontrol, Terdapat hubungan yang signifikan antara motivasi pasien dengan kepatuhan kontrol orthodonti cekat di klinik swasta Yogyakarta

Adapun saran untuk penelitian selanjutnya adalah menggunakan metode penelitian yang berbeda untuk mengetahui motivasi dan tingkat kepatuhan pasien dan faktor-faktor yang mempengaruhinya. Selain itu, dapat diteliti pula mengenai alasan pasien melakukan perawatan ortodontik serta hal-hal yang menyebabkan pasien tidak patuh kontrol.

\section{DAFTAR PUSTAKA}

1. Wijayanti P, Krisnawati, Ismah, N. Gambaran maloklusi dan kebutuhan perawatan ortodonti pada anak usia 9-11 tahun (Studi pendahuluan di SD AtTaufiq, Cempaka Putih, Jakarta). Jurnal PDGI . 2014; 63 (1) : Hal. 25-29

2. Oley A.B, Anindita, P.S, Leman, M.A. Kebutuhan Perawatan Ortodonti Berdasarkan Index Of Orthodontic Treatment Need Pada Usia Remaja 15 17 Tahun. Jurnal e-GiGi (eG). 2015;3( 2).

3. Ay, ZY., Sayin, MO., Ozat, Y., Goster, T, Atilla, AO dan Bozkurt, FY. Appropriate Oral Hygiene Motivation Method for Patients with Fixed Appliances. Angle Orthodontist. 2007; 77(6)

4. Foster T.D. Buku Ajar Ortodonsi. Edisi ke-III. Jakarta: EGC; 1993.

5. Widhiastutiningsih $\mathrm{S}$ Pengetahuan Ortodontik dengan Kepatuhan Kontrol Pasien Ortodontik Cekat di Klinik Bright Dental Care Yogyakarta. Skripsi. Yogyakarta: Poltekkes Kemenkes Yogyakarta; 2013.

6. Lastianny S.P. Dampak Pemakaian Alat Ortodontik Terhadap 2012;19(2):181-184

7. Yovela dan Krisnawati 2009. Penatalaksanaan Kasus Protrusif Gigi Anterior Atas dengan Kelainan Periodontal pada Pasien Dewasa. Indonesian Journal of Dentistry. 2009; 16 (1): 25-31

8. Notoatmodjo S. IImu Perilaku Kesehatan. Jakarta: Rineka Cipta; 2014. 
9. Notoatmojo S. Metodologi Penelitian Kesehatan. Jakarta : Rineka Cipta; 2010.

10. Riwidikdo H. Statistik Kesehatan dengan Aplikasi SPSS dalam Prosedur Penelitian. Yogyakarta: Rohima Press; 2013.

11. Jeremy J, Chung HK. Advances in Orthodontic Treatment. ADA CERP. 2007. p. 2

12. WHO. Adolescent Health. WHO. Accessed December, 2017. http://www.who.int/topics/adolescent heal th/en

13. Herwanda, Arifin R, Lindawaty. Pengetahuan Remaja Usia 15-17 Tahun di SMAN 4 Kota Banda Aceh terhadap Efek Samping Pemakaian Alat Ortodonti Cekat. Journal Of Syiah Kuala Dentistry Society. 2016;1 (1): $79-84$

14. Fajri $L$ dan Sutjiat $R$. Kebutuhan Perawatan Ortodonsi Siswa Sekolah camatan Sumbersari Kabupaten Jember dengan Menggunakan Indeks Handy Capping Malocclusion Assessment Record (Hmar). Stomatogantic (J. K. G Unej). 2013. 10 (1): 47-50

15. Momongan REC, Lampus SB dan Juliatri. Status Kebersihan Gigi dan Mulut Siswa SMA Negeri 9 Manado Pengguna Alat Ortodontik Cekat Skripsi. Manado : Universitas Sam Ratulangi Manado; 2014.

16. Utami SW. Hubungan Perawatan Ortodontik Dengan Status Psikososial Pada Mahasiswa Fakultas Kedokteran Gigi Universitas Hasanuddin. Skripsi. Makassar : Fakultas Kedokteran Gigi Universitas Hasanuddin Makassar; 2014.

17. Sukardi A. Gambaran Motivasi Penggunaan Alat Ortodonti Cekat pada Siswa di 5 SMA Unggul Kota Banda Aceh. Skripsi. Banda Aceh : FKG Unsyiah;2014.

18. Bosh A, Hoogstraten J., dan PrahlAnderson B. Expractations of Treatment and Satisfaction with Dentofacial Appearance in Orthodontic Patient, Am J Orthod Dentofacial Orthop. 2003; 123:127.

19. Paramita S. Siregar E, Sariesendy. Gambaran Tingkat Kooperasi Pasien dengan Perawatan Ortodontik Cekat di Klinik Spesialis Ortodonti RSGM-PFKG
UI. Naskah Ringkas. Jakarta: FKG Universitas Indonesia; 2013.

20. Widhiastutiningsih S. Tingkat Pengetahuan Ortodontik dengan Kepatuhan Kontrol Pasien Ortodontik Cekat di Klinik Bright Dental Care Yogyakarta. Skripsi. Yogyakarta: Poltekkes Kemenkes Yogyakarta; 2013. 